\title{
The Genesis of the Modern Information Society and the Main World Characteristics
}

\author{
Alexey P. Isaev*, Tatyana V. Vasilyeva
}

Russian Presidential Academy of National Economy and Public Administration (North-West Institute of Management of RANEPA), Saint-Petersburg, Russian Federation; *isaev-ap@ranepa.ru

\begin{abstract}
We consider the historical aspect of the formation of the modern information society as a result of the world information revolution. The main stages of the world information revolution are: the Neolithic revolution, iron revolution, the emergence of writing, the invention of printing; the appearance of the telegraph, telephone, radio and television; the emergence of electronic computers, the creation of the Internet.

The idea of the information society was formulated in the late 60 s - early 70 s of the XX century. However, in the 70s of the 20th century there was a convergence of two simultaneously emerging ideologies - the information society and post-industrialism. To date, Information economy is a sector of the information industry of the economic system of the country. The new economic system is highly dynamic, leading to the growth of economic inequality countries, becomes a potential source of conflicts of a different nature. Information, as a reproducible resource, becomes an object of sale and purchase and a source of long-term economic growth. We consider the stages of the world information revolution. The Internet revolution is comparable in its value to the Neolithic and iron revolutions, with the industrial revolution that made the world economy leader England in the 19th century.

We distinguish eight characteristics of the modern information society: unique knowledge, strengthening the role of entrepreneurship, digital technologies, creative highly qualified specialists, the growth of the global online population, the lack of ICT skills, the rapid development of the mobile world, the lack of a unified methodology for measuring ICT skills. The authors come to the conclusion about necessity of creation of uniform world information educational environment for people from all over the world due to the low global level of ICT-skills and the lack of a common methodology for the measurement ICT-skills.
\end{abstract}

Keywords: internet economy, network economy, virtual economy, information (new) economy, information society, entrepreneurship, website, digital products, IT technologies, mobile world, ICT skills

\section{Генезис современного информационного общества и основные мировые характеристики}

\section{Исаев А. П. *, Васильева Т. В.}

Российская академия народного хозяйства и государственной службы при Президенте Российской Федерации (Северо-Западный институт управления РАНХиГС), Санкт-Петербург, Российская Федерация, *isaev-ap@ranepa.ru

\section{РЕФЕРАТ}

Авторы рассматривают исторические аспекты становления современного информационного общества как результат мировой информационной революции. Основные этапы мировой информационной революции: неолитическая революция, железная революция, появление письменности, изобретение книгопечатания, появление телеграфа, телефона, радио и телевидения; появление электронных компьютеров, сеть Интернет.

Идея информационного общества была сформулирована в конце 60-х - начале 70-х годов XX в. В 70-е годы XX в. произошло сближение двух одновременно возникающих идеологий: информационного общества и постиндустриализма. На сегодняшний день информационная экономика - это отрасль информационной индустрии экономической системы страны. Новая экономическая система отличается высокой динамичностью, что приводит к росту экономического неравенства стран, становится потенциальным источ- 
ником конфликтов различного характера. Информация как воспроизводимый ресурс становится объектом купли-продажи и источником долгосрочного экономического роста. Авторы анализируют этапы мировой информационной революции. Интернет-революция сравнима по своему значению с неолитической и железной революциями, с промышленной революцией, которая сделала Англию мировым лидером в XIX в.

Авторы рассматривают восемь характеристик современного информационного общества: уникальные знания, усиление роли предпринимательства, цифровые технологии, креативные высококвалифицированные специалисты, рост мирового онлайн-населения, отсутствие ИКТ-навыков, стремительное развитие мобильного мира, отсутствие единой методологии измерения ИКТ-навыков. Авторы приходят к выводу о необходимости создания единой мировой информационной образовательной среды для людей со всего мира в связи с низким глобальным уровнем ИКТ-навыков и отсутствием единой методологии измерения ИКТ-навыков.

Ключевые слова: интернет-экономика, сетевая экономика, виртуальная экономика, информационная (новая) экономика, информационное общество, предпринимательство, веб-сайт, цифровые продукты, ИТ-технологии, мобильный мир, ИКТ-навыки

\section{The genesis of the information society}

The idea of the information society was formulated in the late 60 s - early 70 s of the $X X$ century. The authorship of the term «information society» is attributed to Y. Hayashi, a professor at the Tokyo Institute of Technology. The Japanese version of the concept of the information society was developed, first of all, to solve the problems of the economic development of Japan, which led to its limited and applied nature. However, in the 70 s of the 20th century there was a convergence of two simultaneously emerging ideologies - the information society and post-industrialism.

The information society is a new post-industrial socio-political and economic organization of a social society with highly developed information and telecommunication infrastructures that provide the possibility of efficient use of intellectual resources to ensure its sustainable and safe development [10].

The transition to an information society implies a change in the entire economic system of society and country, since the growth of the information industry for the national and world economy is becoming ever more significant. The global market for information and telecommunication technologies in recent years has had higher growth rates than the world economy as a whole. According to Gartner Group's ${ }^{1}$ estimates, information technologies have evolved from an auxiliary resource that provides additional business benefits to the main resource necessary for the development of the economy. Digital transformation forces companies to constantly update their business models, and most of the changes will be implemented using digital technologies. Digital technology accelerates changes in business processes in an organization.

The profound influence of the information and telecommunications environment on the current socio-economic processes in society leads to the formation of a new organization of an economic system, for the name of which various concepts are used: «information economy», «network economy», «digital economy», «new economy», «virtual economy», «internet economy», «electronic economy» and others [2] .

Information economy is a sector of the information industry of the economic system of the country. The reflection of the expanded understanding of this concept is presented in the book of Lazarev I. A.: «information economy is an economy of the information society, possessing essentially new forms and properties of post-industrial policy

1 Top 10 Strategic Technology Trends for 2019. 2019. URL: https://www.gartner.com/en/ doc/3891569-top-10-strategic-technology-trends-for-2019 (date of access: 26.02.2019). 
based on the wide informatization of society and practical implementation of information and telecommunication mechanisms of self-organization and harmonization of the state economic system»[10].

When using the concept of «network economy» emphasizes the significant role of Internet technologies in economic development. The technological base of the information society is global telecommunication networks, the largest in the world of which is the Internet, formed by combining more than 10,500 telecommunication networks of various types.

The term «new economy» emphasizes that a new post-industrial stage of development of the economic system is being considered. It seems that the term «information economy» is both generalizing and generally includes all of the listed aspects of the new form of organization and functioning of the economic system of the information society. Thus, the formation of the information economy is a consequence of the need to move to a new post-industrial organization of the socio-economic system based on the use of fundamentally new information, telecommunication and intellectual capabilities in order to increase its efficiency compared with the material production of an industrial society.

At the same time, the creation of a global information network in the process of informatization of a society raises a number of new problems. These problems, first of all, are connected with the construction of interstate relations in the new conditions of information transparency of state borders. There is a need to develop a rational policy in terms of the entry of national telecommunication networks into global networks and ensuring the information security of states.

Open networks can be a tool for the informational, political, and cultural expansion of information technology-developed countries in relation to developing countries. With the formation of the information society and the information (new) economy, the role of countries increases. The most important task of the country is to define and implement policies aimed at creating the necessary conditions for sustainable economic development.

The new economic system is highly dynamic, leading to the growth of economic inequality and instability of the "weaker» countries, which becomes a potential source of conflicts of a different nature. This factor should be taken into account when developing a strategy for the sustainable development of civilization in the conditions of the formation of an information (new) economy.

The development of information technology began with the advent of writing, and then printing. New technologies created new forms of employment:

- in the XII-XIX centuries - the publication of books, magazines and newspapers;

- in the late XIX - early XX century - telegraph and telephone;

- in the middle of the XX century - a television.

The emergence of electronic computers based on information technology has radically changed the structure of the economy. The emergence of electronic computers has turned intelligent technology into the most important tool for system analysis, the basis for making management decisions. Thus, intellectual, scientific technology, provided an opportunity to replace intuitive solutions with clear algorithms, and science has become a fully productive force. In the «new» knowledge-based economy, new needs and new technologies are constantly emerging. A new economy needs creatively thinking, skilled and versatile workers who are able to quickly rebuild, combine research, management and executive functions, quickly make decisions according to changes in production.

Information, as a reproducible resource, becomes an object of sale and purchase and a source of long-term economic growth. One of the most important ways to disseminate information in the «new» economy is the Internet. The modern Internet revolution is transforming the economic, social and political structure of society. The stages of the world information revolution are presented in the Figure 1.

The Internet revolution is comparable in its value to the Neolithic and iron revolutions, with the industrial revolution that made the world economy leader England in the 19th 


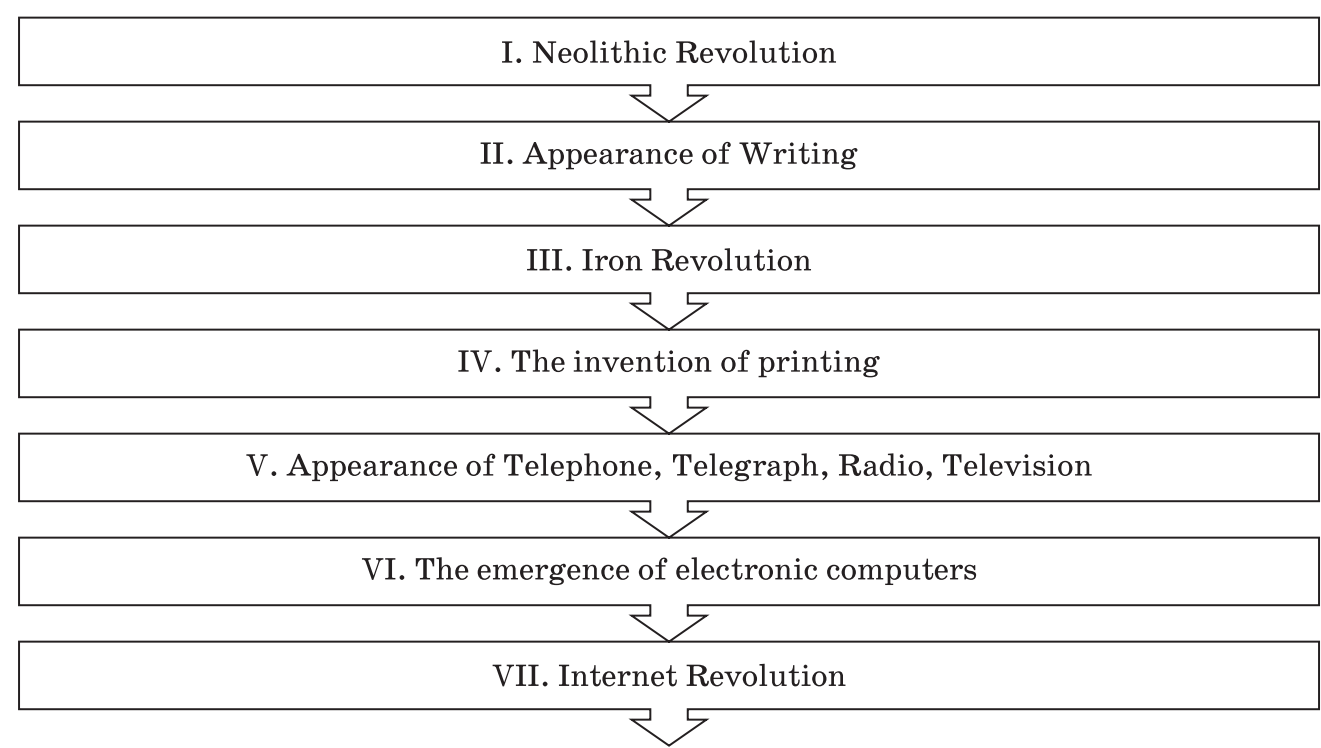

Figure 1. Stages of the world information revolution [9, p. 28]

century, and at the beginning of XX century - USA. The main stages of the world information revolution are: the Neolithic revolution, iron revolution, the emergence of writing, the invention of printing; the appearance of the telegraph, telephone, radio and television; the emergence of electronic computers, the creation of the Internet.

The emergence and transformation of the global Internet from a simple source of information into a means of international communication, a tool for the economic integration of countries and an effective way to reduce the costs of manufacturing companies have led to an Internet revolution taking place all over the world. The Internet revolution is a fundamental change in the life of society, associated with the ubiquity of the global telecommunications Internet. In terms of its scale, the Internet revolution can be compared to the spread of television: in 1950, $9 \%$ of families had televisions, and through ten years later, in $1960,87 \%$ of families already had it.

The problems of ensuring sustainable and safe development of society are fundamental both in scientific and applied plans at the present time. In modern conditions there is a reduction of natural resources, environmental degradation and the growth of threats to the progressive development of our civilization. Considerable interest arises in assessing the impact of the intensive development of global information and telecommunication technologies on society and the economy of the 21 st century [3, p. 135].

The formation of a global information and communication environment opens up fundamentally new opportunities in various areas of human social and economic activity. The global information and communication environment allows us to consider the post-industrial stage of civilization development as a process of transition to a fundamentally new socio-economic structure - the information society and the new type of economy that forms its basis, namely, the information economy.

Initially, the main provisions of the concept of post-industrial society are reflected in the works of D. Bell, E. Masud, E. Tofler, R. Drukergui. The concept of post-industrialism is widely disclosed in D. Bell's book «The Offensive of Post-Industrial Society. The Experience of Social Forecast», published in 1973. The variant of the convergence of ideas of post-industrialism and the information society in D. Bell's research is presented 
in 1980 by the book «The Social Framework of the Information Society» [9, p. 29].

The expression «information society» by $\mathrm{D}$. Bell is a new name for a post-industrial society, emphasizing not its position in the sequence of stages of social development after industrial society - but the basis for determining its social structure - information.

According to the concept of post-industrialism, there are three periods: pre-industrial society, industrial society and post-industrial society. The basic concepts of the postindustrial society are presented in Table 1.

Table 1

The concept of a post-industrial society

\begin{tabular}{|l|l|l|l|}
\hline \multicolumn{1}{|c|}{$\begin{array}{c}\text { Society/ } \\
\text { Signs }\end{array}$} & $\begin{array}{c}\text { Pre-industrial } \\
\text { society }\end{array}$ & \multicolumn{1}{|c|}{ Industrial society } & \multicolumn{1}{|c|}{ Post-industrial society } \\
\hline Main industry & Agriculture & Large industry & $\begin{array}{l}\text { Services (health, } \\
\text { education, research, } \\
\text { management) }\end{array}$ \\
\hline Main property & Land & $\begin{array}{l}\text { Industrial and } \\
\text { financial capital }\end{array}$ & $\begin{array}{l}\text { Information and } \\
\text { knowledge }\end{array}$ \\
\hline $\begin{array}{l}\text { Leading Socio- } \\
\text { Economic and Political } \\
\text { Power of Society }\end{array}$ & Landowners & Owners of capital & $\begin{array}{l}\text { Scientists and } \\
\text { professional specialists }\end{array}$ \\
\hline
\end{tabular}

D. Bell formulates the problem of the information theory of value and the information (service) economy: "When knowledge in its systematic form is involved in the practical processing of resources (in the form of an invention or organizational improvement), we can say that it is knowledge, not labor, that is the source of value» [6].

A comparative analysis of pre-industrial society, industrial society and post-industrial societies is presented in Table 2 .

Table 2

The basics of pre-industrial, industrial and post-industrial societies

\begin{tabular}{|c|l|l|l|}
\hline $\begin{array}{c}\text { Society/ } \\
\text { Basics }\end{array}$ & Pre-industrial society & Industrial society & Post-industrial society \\
\hline $\begin{array}{l}\text { Basics } \\
\text { of society }\end{array}$ & $\begin{array}{c}\text { labor-intensive } \\
\text { technologies; } \\
\text { the use of human } \\
\text { muscular strength; } \\
\text { not requiring long } \\
\text { learning skills; } \\
\text { exploitation of } \\
\text { natural resources }\end{array}$ & $\begin{array}{c}\text { machine production; } \\
\text { capital-intensive } \\
\text { technologies; } \\
\text { the use of } \\
\text { extramuscular } \\
\text { energy sources; } \\
\text { requiring a long } \\
\text { training } \\
\text { qualification } \\
\text { information and } \\
\text { knowledge, as the } \\
\text { main production } \\
\text { resource; } \\
\text { the creative aspect of } \\
\text { human activity; } \\
\text { continuous self- } \\
\text { improvement and } \\
\text { advanced training } \\
\text { throughout life }\end{array}$ \\
\hline
\end{tabular}

\section{Special characteristics of the information society and the current state of ICTs in the world}

The main features of the modern information society are presented in Figure 2.

1. The prevalence of knowledge over capital, unique knowledge 


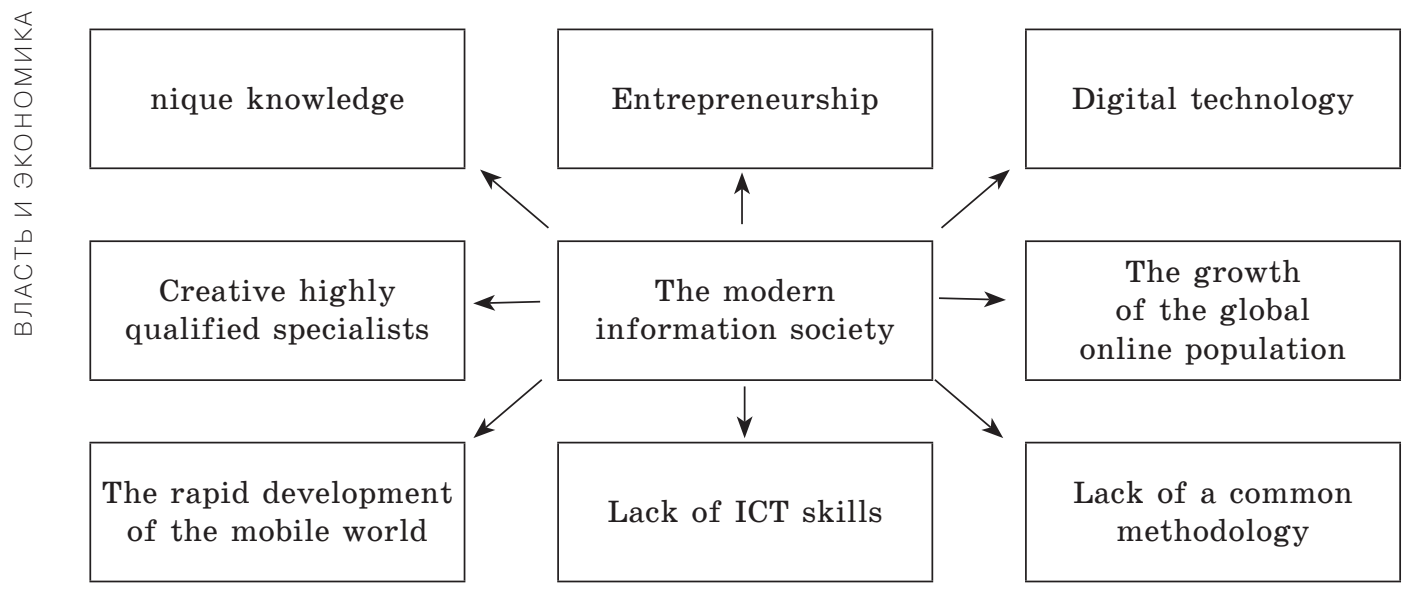

Fig. 2. Eight main characteristics of the modern information society

At the first stages of an industrial society, with capital, it was almost always possible to organize the mass production of any product and occupy a niche in the market. With the development of competition, especially international, the amount of capital does not guarantee protection against failure and bankruptcy. Innovation is imperative for success. Capital cannot automatically ensure the appearance of the know-how necessary for economic success and, conversely, in the post-industrial sectors of the economy, the availability of know-how makes it easy to raise the necessary capital even without having its own [4].

The value of corporations in a information society is mainly due to intangible assets know-how, employee qualifications, business structure efficiency, etc. For example, the capitalization of Microsoft corresponds to the capitalization of the largest mining companies, although Microsoft has orders of magnitude less than tangible assets.

\section{Strengthening the role of entrepreneurship}

In a information society, the importance of mass production is declining, which is moving to other regions. The role of entrepreneurshipis increasing, more and more small-scale goods are being produced with many modifications and options for services in order to meet the needs of different groups of consumers [1].

\section{Technological changes in information society, digital technology}

Technological progress in the industrial society was achieved mainly due to the work of inventors and practitioners, who often had no scientific training (for example, T. Edison). In the information society, the applied role of scientific research, including fundamental research, is sharply increasing. The main technologies that receive the greatest development in the information society are high-tech, resource-saving and information technologies («high technologies»). Thanks to informatization, mechanical interactions are replaced by electronic technologies, and biological organisms change at the gene level. The main trends in technological processes are becoming: increasing automation based on digital technologies, replacing unskilled labor with machines and computers.

\section{The social structure of the information society and importance of the human factor}

An important feature of the information society is the strengthening of the role and importance of the human factor [8, p. 94]. The structure of labor resources is changing: the share of the physical is decreasing and the share of highly skilled and creative labor 
is growing. The cost of training the workforce is increasing: the cost of training and education, advanced training and retraining of workers.

With the development of information society, information becomes the most important economic category and a source of additional profits. Possession of systematically organized information is transformed into economic advantages, ensuring the redistribution of natural resources, labor and capital with the opening of new opportunities for all types of production, economic and financial activities.

\section{Online population in the world is growing}

At the end of 2018, 51.2 percent of people used the Internet, or 3.9 billion people ${ }^{1}$. In developing countries, however, there is still plenty of room for growth: with 45 percent of people using the Internet. Internet consumption remains relatively low in 47 least developed countries (LDCs) and four out of five people ( 80 per cent) are not yet using the Internet.

\section{Mobile-cellular telephone subscriptions is already greater than the global population}

Broadband access continues to sustained growth. Almost the whole world population now lives within range of a mobile-cellular network signal. In addition, most people can access the Internet through a $3 G$ or higher-quality network. This evolution of the mobile network, however, is going faster than the growth in the percentage of the population using the Internet. Internet access at home is gaining traction. Almost 60 per cent of households had Internet access at home in 2018, up from less than 20 per cent in $2005^{2}$. Fewer than half of households had a computer at home, highlighting that a substantial number of households accessed the Internet (also) through other means, most importantly through mobile devices, often using the data plan of the mobile-broadband subscription. Three quarters of the world's population owned a mobile phone in 2017 , but in LDCs this proportion stood at 56 per cent.

\section{Lack of ICT skills}

Lack of ICT skills is an important impediment for people to access the Internet. Data of the «Measuring the Information Society Report 2018» show that, as activities get more complex, fewer people undertake these activities. More importantly, computer users in developed countries seem to possess more ICT skills than users in developing countries, pointing to a serious constraint on the development potential of developing countries and LDCs.

For people of the future, it becomes important to have a wide range of ICT skills: technical operational, information management, social and content-creation skills. Data of the «Measuring the Information Society Report 2018» show that, A third of individuals lack basic digital skills, such as copying files or folders or using copy and paste tools; a mere 41 per cent have standard skills, such as installing or configuring software or using basic formulas on spreadsheets; and only 4 per cent are using specialist language to write computer programs.

\section{Lack of a common methodology for the collection, analysis and processing of digital data}

There are problems in collecting data for certain countries and groups, as well as a limited range of methodological tools. Proxy measurements (such as a request to measure

\footnotetext{
${ }^{1}$ Measuring the Information Society Report Executive summary 2018. URL: https://www.itu.int/ en/ITU-D/Statistics/Documents/publications/misr2018/MISR2018-ES-PDF-E.pdf (date of access: 26.02.2019).

2 Measuring the Information Society Report Executive summary 2018.
} 
a skill) and self-assessment of skills are the most common now. Recently, self-assessment is evaluated using scales that have been tested using performance tests (proxy test performance surveys). The least common are the actual tests and official exams on ICT skills of the population of the country. It is recommended that survey measures be developed that can be used for larger population groups. There is an urgent need to develop measures across the spectrum of ICT skills: operational information processing, information management skills, communication skills and content creation in the ICT environment. These elements should be device and platform independent, it is important to measure skills, not actions.

\section{Summary}

Information and communication technologies have an impact on all aspects of modern society. In the new information society, unique information becomes the main driving force. Highly qualified specialists who are able to collect, quickly analyze large amounts of information and on this basis to create something new, become the basis of the modern information society.

The rapid growth of the online population combined with the low global level of ICT skills leads to the need to create a unified information learning environment for people from all over the world. However, the creation of such a technology platform requires addressing a number of important issues, including the creation of a common methodology for measuring ICT skills.

\section{References}

1. Isaev A.P., Vasilyeva T.V. The system of infrastructure ensuring business activity in the market of mobile commerce of Russia // Administrative consulting [Upravlencheskoe konsul'tirovanie]. 2019. N 3. P. 41-48. (In rus)

2. Isaev A. P., Vasilyeva T. V. About implementation of the program "Digital Economy of the Russian Federation" // Eurasian integration: economy, law, policy [Evraziiskaya integratsiya: ekonomika, pravo, politika]. 2018. N 1. P. 46-57. (In rus)

3. Isaev A.P., Vasilyeva T.V. National peculiarities of business in the market of mobile commerce of Russia // Administrative consulting [Upravlencheskoe konsul'tirovanie]. 2018. N 11. P. 132 138. (In rus)

4. Kudryashov V.S. Implementation of cluster policy for economic development of regions of Russia // Economy and management: problems, decisions [Ekonomika i upravlenie: problemy, resheniya]. 2017. N 1. P. 33-38. (In rus)

5. Maksiyanova T.V. Influence of Internet economy on GDP of Russia // Questions of modern science and practice. University of V.I. Vernadsky [Voprosy sovremennoi nauki i praktiki. Universitet im. V.I. Vernadskogo]. 2012. N 2. P. 177-187. (In rus)

6. Bell D. The coming of post-industrial society: A venture of social forecasting. N.Y. : Basic Books, 1973.

7. Maksiyanova T.V. The place and a role of Internet commerce in the system of Internet economy at the present stage of development of information (new) economy // Questions of modern science and practice. University of V.I. Vernadsky [Voprosy sovremennoi nauki i praktiki. Universitet im. V.I. Vernadskogo]. 2011. N 3. P. 256-264. (In rus)

8. Vasilyeva T. V. Interaction of subjects of digital economy of Russia // Questions of modern science and practice. University of V.I. Vernadsky [Voprosy sovremennoi nauki i praktiki. Universitet im. V. I. Vernadskogo]. 2018. N 3. P. 91-96. (In rus)

9. Bell D. (1980) "The Social Framework of the Information Society", in T. Forester (ed.) The Microelectronics Revolution, Oxford : Blackwell. P. 500-549.

10. Lazarev I. A., Hizha G. S., Lazarev K.I. 2006. New information economy and network development mechanisms. Publishing and trading corporation «Dashkov and $\mathrm{K}$ ".

11. Maksiyanova T. V. Principles of organization and factors of Internet commerce development. Questions of modern science and practice. University named after Vernadsky. 2011. N 2. P. 277-281. 
12. Maksiyanova T.V. 2012. Innovative changes in the Russian economy under the influence of Internet economy formation and development // World Applied Sciences Journal. N 20. P. $1307-$ 1312.

13. Maksiyanova T. V., 2011. Risks of dotcom companies. Questions of modern science and practice. University named after Vernadsky. 4 (35). P. 274.

\section{About the authors:}

Alexey P. Isaev, Dean of Faculty of Economy and Finance of North-West institute of management of RANEPA (St. Petersburg, Russian Federation), Doctor of Science (History), Professor; isaevap@ranepa.ru

Tatyana V. Vasilyeva, Associate Professor of the Chair of Economics of the North-West Institute of Management of RANEPA (St. Petersburg, Russian Federation), PhD in Economics, Associate Professor; 15351538@mail.ru

\section{Литература}

1. Исаев А. П., Васильева Т.В. Система инфраструктурного обеспечения предпринимательской деятельности на рынке мобильной коммерции России // Управленческое консультирование. 2019. № 3. С. 41-48.

2. Исаев А. П., Васильева Т.В. О реализации программы «Цифровая экономика Российской Федерации» // Евразийская интеграция: экономика, право, политика. 2018. № 1. С. 46-57.

3. Исаев А. П., Васильева Т.В. Национальные особенности предпринимательства на рынке мобильной коммерции России // Управленческое консультирование. 2018. № 11. С. 132138.

4. Кудряшов В.С. Реализация кластерной политики в целях экономического развития регионов России // Экономика и управление: проблемы, решения. 2017. № 1. С. 33-38.

5. Максиянова Т.В. Влияние интернет-экономики на ВВП России // Вопросы современной науки и практики. Университет им. В.И. Вернадского. 2012. № 2. С. 177-187. (16).

6. Bell $D$. The coming of post-industrial society: A venture of social forecasting. N.Y. : Basic Books, 1973.

7. Максиянова Т.В. Место и роль интернет-коммерции в системе интернет-экономики на современном этапе развития информационной (новой) экономики // Вопросы современной науки и практики. Университет им. В.И.Вернадского. 2011. № 3. С. 256-264.

8. Васильева Т.В. Взаимодействие субъектов цифровой экономики России // Вопросы современной науки и практики. Университет им. В.И. Вернадского. 2018. № 3. С. 91-96.

9. Bell D. (1980) "The Social Framework of the Information Society", in T. Forester (ed.) The Microelectronics Revolution, Oxford: Blackwell. P. 500-549.

10. Lazarev I. A., Hizha G. S., Lazarev K. I. 2006. New information economy and network development mechanisms. Publishing and trading corporation «Dashkov and K».

11. Maksiyanova T.V. Principles of organization and factors of Internet commerce development. Questions of modern science and practice. University named after Vernadsky. 2011. N 2. P. 277-281.

12. Maksiyanova T.V. 2012. Innovative changes in the Russian economy under the influence of Internet economy formation and development // World Applied Sciences Journal. N 20. P. 13071312.

13. Maksiyanova T.V., 2011. Risks of dotcom companies. Questions of modern science and practice. University named after Vernadsky. 4 (35). P. 274.

\section{Об авторах:}

Исаев Алексей Петрович, декан факультета экономики и финансов Северо-Западного института управления РАНХиГС (Санкт-Петербург, Российская Федерация), доктор исторических наук, профессор; isaev-ap@ranepa.ru

Васильева Татьяна Владимировна, доцент кафедры экономики Северо-Западного института управления РАНХиГС (Санкт-Петербург, Российская Федерация), кандидат экономических наук, доцент; 15351538@mail.ru 